\title{
Center of Laboratory Project (CoLaP) Needs Analysis In Learning
}

\author{
Tiur Malasari Siregar ${ }^{1, *}$ Suci Frisnoiry ${ }^{1}$ Elfitra ${ }^{1}$
}

\author{
${ }^{1}$ Universitas Negeri Medan, Jl. William Iskandar Psr. V Medan Estate \\ ${ }^{*}$ Corresponding author. Email: tiurmalasarisiregar@unimed.ac.id
}

\begin{abstract}
This research is focused on analyzing the needs of Center of Laboratory Project $(\mathrm{CoLaP})$ in learning process, where the need for learning media in the era of information technology that is swiftly affects the teaching and learning process. In this case we focus on analyzing 1) Curriculum analysis, 2) Laboratory condition analysis, 3) Infrastructure development analysis and 4) Media Development Needs Analysis in entering the era of incessant technological innovation so that inevitably demands an education system that is matched with the demands of education development that leads to working environment. The need of innovative learning medias, especially in overcoming the distance learning system, the intensity of the use effectiveness of learning media on learning outcomes. Research data were collected through literature study, observation, document recording and interviews. Sources of research data are 250 students who take laboratory courses from 25 lecturers who are tasked a lecturers of laboratory courses and 4 laboratory assistants. The data obtained were analyzed descriptively and evaluatively and the conclusion were described qualitatively.
\end{abstract}

Keywords: Center of laboratory project, learning.

\section{INTRODUCTION}

Information technology has developed swiftly and has a tremendous influence on education, one of which we can feel in the development of learning media that we use in education which is now assisted by computers and the internet. Entering an era that marked by incessant technological innovation so that inevitably demands an education system that is matched with the demands of educational development that leads to working environment.

In learning implementation, a laboratory is needed with the aim of providing psychomotor skills where these skills will develop if often repeated and practiced so that students will have skills in using equipment and media that are provided in the laboratory. This ability is very necessary for students who will be able to compete working environment. This statement is supported by [1], which stated the cognitive learning outcomes will correlate with their psychomotor abilities, besides those students who get high learning outcomes also have good affective characters. Furthermore, [2], stated that students' psychomotor skills in biochemistry practicums are also influenced by their cognitive abilities, as well as students' cognitive abilities that can be influenced by their psychomotor skills during the practicum learning process.

In improving the laboratory, innovations are needed so that the laboratory can develop in accordance with technological developments that are in line with the development of science. Like the Center of Laboratory Project $(\mathrm{CoLaP})$ which is a laboratory learning center at the Mathematics Education study program at Universitas Negeri Medan, a laboratory that provides teaching aids, software which is related to learning applications, data processing software and others, can be said to be a learning center for students. The statement is also supported by [3] which stated that the laboratory is a place to carry out experimental or practical activities where students will better understand the subject matter if they are actively involved in the learning process such as knowing, understanding, and also mastering the material well by observing activities and conducting experiments in laboratory.

Laboratory is a place to carry out work activities to produce something [4]. Furthermore, [5] stated that laboratory is a place to conduct experiments, investigations and so on that related to science. The laboratory is a teaching and learning infrastructure [6]. From some of those opinions, it can be concluded that the 
laboratory is a learning center to carry out an exercise, experiment, and learning.

The learning laboratory or what we call as student learning center can be used according to the schedule set by the laboratory assistant who is in charge of setting the schedule for the use of the laboratory starting from the first semester to the eighth semester for the learning process, but beyond that laboratory can still be used by students to develop themselves related to the knowledge of applications that are developing in learning and laboratory can also be used as a place to carry out research, service and others. In creating a good quality laboratory, various efforts are required, one of which analyze the needs in learning, interactive multimedia that can provide the latest information that can increase students' abilities and knowledge in developing themselves. The above statement is also supported by [7], virtual laboratories are used to improve the competence of vocational school students in terms of cognitive, psychomotor, and student character.

Good learning quality requires good learning facilities, one of which CoLaP with complete facilities can support to balance and fulfill student curiosity, desire to try new things in learning, fulfill course projects such as learning to make, then re-teaching it, doing research, community service all of these become areas for selfdevelopment. The increasing professionalism of lecturers was marked by improving the quality of the development result of teaching materials, the ability to master materials, methodologies, the use of information and communication technology in lectures [8].

By conducting a needs analysis, which is currently one of the development processes of CoLaP, the results of this analysis will be used to design practical learning in $\mathrm{CoLaP}$, which will eventually produce digital or virtual-based media. Then, we can evaluate the media to produce digital or virtual media products as mentioned [7]. A virtual laboratory is defined as an interactive environment for creating and conducting simulation experiments: a playground for experimenting. It consists of domain dependent simulation program, experimental unit called object that includes data files, tools that operate on the object, and reference book. The same opinion is also supported by (Emigh \& Herring, 2005) who stated that virtual environments, named virtual laboratory, vary from static web pages with video and text to dynamic pages with sophisticated, collaborative authoring environments.

This CoLap analysis in Learning focuses on the learning curriculum laboratory that will be applied, laboratory conditions, the development of facilities and infrastructure to support learning activities and the need for learning media, especially e-learning or virtual media. Needs analysis is carried out through literature studies by observing the curriculum of several courses in laboratory, while field studies are carried out by collecting information related to laboratory conditions, development of infrastructure and media users in learning.

\section{METHOD}

To achieve the expected objectives, this type of research was designed using a descriptive qualitative approach to obtain the portrait of Center of Laboratory Project (CoLaP) needs analysis in learning. The design of $\mathrm{CoLaP}$ analysis in learning is as follows:

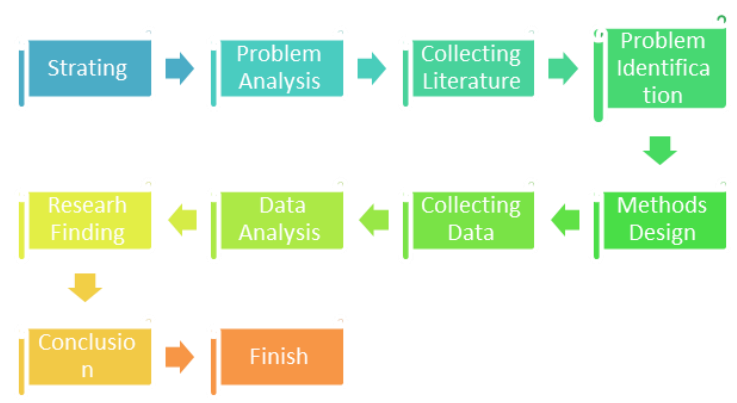

Figure 1 Research Flowchart.

This research was conducting in Mathematics Education laboratory. The subjects of this research were students, laboratory assistants, lecturers in mathematics, the data collection method used was to collect some literature that supports the CoLaP needs analysis, observation, interviews, and questionnaires. Literature study is intended to support the statements in the research. Observation of the situation and condition of laboratory during offline and online lectures, interviews and questionnaires for students, laboratory assistants and lecturers. The data obtained are qualitative data followed by analyzing descriptively with a qualitative approach.

\section{RESULT AND DISCUSSION}

Center of Laboratory Project (CoLaP) Needs Analysis in Learning is an initial activity that conducting before developing a multimedia laboratory that is in accordance with the courses and learning needs. The first conducting analysis is a literature study related to the laboratory condition curriculum, infrastructure and media development. Furthermore, Sudaryanto stated that there are three roles and functions of laboratory, namely as (1) learning resources, meaning that laboratory is used to solve problems related to the cognitive, affective and psychomotor domains or to conduct experiments, (2) educational methods, which include observation methods and experimental methods, and (3) research facilities, which are places where various researches are conducting so as to form students' personalities who have a scientific attitude. Murwaningsih (2015) also said that in the learning process there are many factors that determine whether a graduate's competence is good. The factors include the availability of adequate laboratory in accordance with learning objectives. Laboratory plays an 
important role in improving student skills. Facilities are everything that directly supports the smooth learning process. One of the learning facilities is laboratory [9]. Sanjaya (2015), laboratory in chemistry learning involves students in concrete experiences that obtained through laboratory activities which are very important for students in the learning process. Learning will be more effective if students reflect on their own experiences and try to use what they learn.

\subsection{Curriculum Analysis}

CoLaP needs analysis in terms of the courses taught is prepared by taking into the profile of graduates. Mathematics education is to become an outstanding and characterized mathematics teacher. The competencies of mathematics education graduates are:

- Be able to manage learning and arrange mathematics learning tools in accordance with mathematical concepts

- Be able to analyze Mathematics

- Be able to solve problems in mathematics

- Be able to communicate effectively

- Be able to manage mathematics facilities and infrastructure (laboratory)

- Be able to operate media with the latest applications that support learning

With the competencies that have been described, it is hoped that mathematics education graduates will have competitiveness in working environment, both at regional, national and international levels. Applying learning media with new software is the most important thing in analyzing the need for CoLaP, so that a quality laboratory is needed to support the achievement of good quality, CoLaP facilities and infrastructure are very much needed as well as human resources that are truly in accordance with their field of expertise.

\subsection{Conditions of the Mathematics Education Laboratory}

Currently, CoLaP has 3 lab rooms, namely the teaching aids laboratory, the matlab laboratory, and the statistics laboratory. The condition of the laboratory for now is very unrepresentative because many infrastructure facilities are not in accordance with current learning, especially the learning system for the last two years is distance learning with full online which results in this laboratory being very poorly functioned with less supportive infrastructure and software that is difficult to access from home, many materials are difficult to teach with limited equipment in the learning process, but for activities such as student and lecturer research and community service, statistical data processing conducting through offline is still functioning with strict health procedures. Therefore, it is very necessary to develop learning media, the latest software whose functions and benefits are adjusted to the development of science and technology so that online learning can be conducted and accessed by students through distance learning and the learning process continues to run according to the learning objectives to be achieved.

\subsection{Conditions of Facilities and Infrastructure Development}

The development of laboratory is a must so that all activities that conducting follow the development of learning science and technology. CoLaP development is the development of infrastructure. The development of this facility is the development of a laboratory room in accordance with the needs of the course, while the development of this facility is the development of laboratory equipment and needs to support the learning process based on technology and information and no less important is the development of human resources such as lecturers who understand the material and its application, laboratory assistants who understand how to use software and media in the mathematics education laboratory.

Currently, the teaching aids laboratory is still using print modules and conventional media while the online learning process, there is difficulty in teaching the media with the development of facilities and infrastructure that will design learning modules using e-books and teaching aids that are taught also lead to digital props. Then, for matlab and statistics laboratories, also need tools that we use to develop virtual media such as virtual reality, augmented reality, holograms and others, developing ebook laboratory manuals that can be used for online learning, which can add improvements to the use of laboratories in supporting learning such as adding competent laboratory assistants. In empowering lecturers, lecturers who understand technology should be able to use its applications.

\subsection{The Needs of Media Development}

This media development is related to the supporting infrastructure that needed when conducting the learning process. There are four laboratory courses, namely: teaching aids, matlab, statistics and digital learning media. All of this needs to be upgraded starting from laboratory manuals in the form of e-books, virtual learning that requires tools, such as Virtual reality and Augmented reality requiring the help of tools, statistical data processing requires new software that can be accessed by all students and applying learning media distance, such as 3D VR glasses that has the function as technology that makes the objects we observe real and brings us into a three-dimensional atmosphere. With the use of VR technology, it is hoped that it will improve educational standards. In addition, this technology will also be able to become an interactive learning media so that it can reduce students for being passive. Teachers can 
deliver learning materials in a more interesting way and students can more easily catch what is conveyed by the teacher.

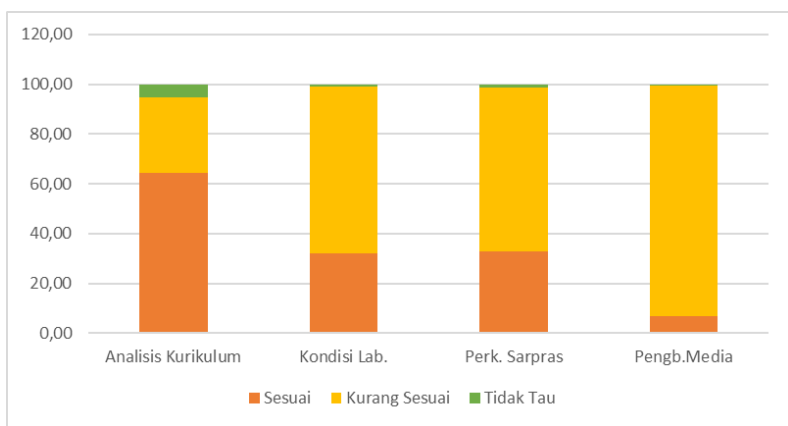

Figure 2 CoLaP Needs Analysis.

From the graphic chart of the CoLaP needs analysis, it can be seen that 180 people or $64.52 \%$ answered appropriate, 84 people or $30.11 \%$ said they were not suitable and 15 people or $5.38 \%$ answered they did not know related to curriculum analysis for laboratory courses with the material taught in the laboratory. Here it can be seen that the curriculum is almost in accordance with the profile of graduates of Mathematics Education but still needs to make revisions related to the learning system that we are currently running to make it more supportive for our current graduate profile. For the case of laboratory conditions, 89 people or $31.90 \%$ answered accordingly, 187 people or $67.03 \%$ answered less appropriate and 3 people or $1.08 \%$ answered they did not know. In this case, the laboratory conditions are still not good, but to support online learning we are currently experiencing, it is still very necessary to make improvements or additions to laboratory rooms including virtual laboratory and digital laboratory.

In analyzing the development of facilities and infrastructure, 92 people or $32.97 \%$ of respondents answered accordingly, 183 people or $65.59 \%$ of respondents answered less appropriate and 4 people or $1.43 \%$ of respondents answered they did not know. From this data, the infrastructure owned by CoLaP, such as equipment that supports virtual learning and digital laboratories. Meanwhile, 19 people or $6.81 \%$ of respondents answered accordingly, 258 people or $92.47 \%$ of respondents answered less appropriate and 2 people or $0.72 \%$ answered they did not know. So, it can be concluded that for CoLaP it is very necessary to develop learning media, be it virtual or digital.

\section{CONCLUSION}

The findings of CoLaP needs analysis in learning are that the role of the laboratory is needed and functions in supporting the learning, research and service processes, both for students, laboratory assistants and for lecturers. From the results of the curriculum analysis, it can be seen that $64.52 \%$ of respondents answered that they were appropriate but still needed adjustments to our current learning process, $67.03 \%$ of respondents gave answers that were still not appropriate, which means improvements or additions to laboratory, especially for virtual and digital learning needs which are currently is a very major need in online learning, as well as for supporting infrastructure $65.59 \%$ of respondents stated that it is still not suitable because it is directly proportional to the needs of virtual and digital learning and the center of attention is the development of laboratory learning media, $92.47 \%$ of respondents stated that the development of this learning media really needs special attention, because the development of this media will greatly affect learning, whether it be a learning media, course output, project assignments, research developments for both students and lecturers, community service to school teachers, students and all partners who need CoLaP as a learning center.

\section{REFERENCES}

[1] V. Sönmez, Association of Cognitive, Affective, Psychomotor and Intuitive Domains in Education, Sönmez Model, Universal Journal of Educational Research, vol. 5, 2017, pp. 347-356. DOI: https://doi.org/10.13189/ujer.2017.050307

[2] Puspitasari et.al., Analisis Keterampilan Psikomotorik Mahasiswa Pada Praktikum Biokimia dan Korelasinya dengan Hasil Belajar Kognitif, Jurnal Pendidikan Biologi, vol. 8, 2018, pp. 31 - 38 . DOI:

http://jurnal.unimed.ac.id/2012/index.php/JPB

[3] A. Emda, Laboratorium Sebagai Sarana Pembelajaran Kimia dalam Meningkatkan Pengetahuan dan Keterampilan Kerja Ilmiah, Lantanida Journal, vol. 2, 2014, pp. 218-229. DOI: http://dx.doi.org/10.22373/lj.v2i2.1409

[4] Sukarso, Pengertian dan Fungsi Laboratorium. Online, 2005. Retrieved from: http://wanmustafa.wordpress.com/2011/06/12/peng ertian-dan- fungsi-laboratorium

[5] S.M. Emha, Pedoman Penggunaan Laboratorium Sekolah, Remaja RosadakaryaBandung, 2002.

[6] N.L. Supadmi, Pengaruh Kualitas Pelayanan, Sanksi Perpajakan, Biaya Kepatuhan, dan Penerapan Efilling Pada Kepatuhan Wajib Pajak, E-Jurnal Ekonomi dan BisnisUniversitas Udayana, vol. 14, 2016, pp. 1239-1269.

[7] H. Jaya, Pengembangan Laboratorium Virtual Untuk Kegiatan Praktikum Dan Memfasilitasi Pendidikan Karakter Di Smk, Jurnal Pendidikan Vokasi, vol. 2, 2012, pp. 81-90. DOI: https://doi.org/10.21831/jpv.v2i1.1019 
[8] A. Agoestanto, Meningkatkan Kualitas Pembelajaran Pada Mata Kuliah Pengantar Probabilitas Melalui Lesson Study Dengan Pengajaran Berbalik Secara Team, JURNAL KREANO, vol. 3, 2012. DOI: https://doi.org/10.15294/kreano.v3i1.2611

[9] W. Sanjaya, Wina, Strategi Pembelajaran Berorientasi Standar Proses Pendidikan, Prenada Media Group, Jakarta, 2010. 